\title{
Probable root structures and associated trace fossils from the Lower Pleistocene calcarenites of Favignana Island, southern Italy: dilemmas of interpretation
}

\author{
Alfred UCHMAN, Andrzej ŚLĄCZKA and Pietro RENDA
}

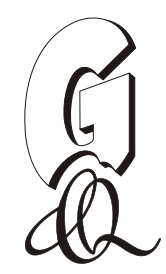

\begin{abstract}
Uchman A., Ślączka A. and Renda P. (2012) - Probable root structures and associated trace fossils from the Lower Pleistocene calcarenites of the Favignana Island, southern Italy: dilemmas of interpretation. Geol. Quart., 56 (4): 745-756, doi: 10.7306/gq.1052

Two types of large, branched structures from the Lower Pleistocene (Calabrian) high-energy calcarenites of Favignana Island are described: Faviradixus robustus gen. et sp. nov. and Egadiradixus rectibrachiatus gen. et sp. nov. They may be interpreted as root structures of large plants, i.e., trees and trees or shrubs, respectively. The former taxon co-occurs with the marine animal trace fossils Ophiomorpha nodosa, Ophiomorpha isp., Thalassinoides isp. and Beaconites isp. The interpretation as root structures although tentative is probable and can be related to short emergence episodes for the formation of E. rectibrachiatus or to longer emergence, responsible for the discontinuity at the base of the overlying Tyrrhenian deposits, for F. robustus. Calcified root mats of smaller plants associated with the Tyrrhenian or younger emergence surfaces are common.
\end{abstract}

Alfred Uchman and Andrzej Ślqczka, Institute of Geological Sciences, Jagiellonian University, Oleandry 2a, 30-063 Kraków, Poland, e-mails: alfred.uchman@uj.edu.pl, andrzej.slaczka@uj.edu.pl; Pietro Renda, Dipartimento di Geologia, Università di Palermo, Via Archirafi 20/22, 90100 Palermo, Italy, e-mail: renda@ unipa.it (received: April 24, 2012; accepted: September 12, 2012; first published online: November 5, 2012).

Key words: ichnology, root structures, burrows, carbonates, Quaternary, Mediterranean Sea.

\section{INTRODUCTION}

Distinguishing between animal trace fossils and root structures is not always easy (see Boyd, 1975; Sarjeant, 1975; Klappa, 1980; Gregory and Campbell, 2003), mainly because the morphology of fossil root systems is much less understood than that of animal trace fossils. Klappa (1980), Curran (1984), and Ekdale et al. (1984) provided criteria for the distinction between roots and animal burrows; however, their application is not always straight forward. Moreover, the primary morphology of roots can be considerably transformed diagenetically, leading to formation of different mimicking features. For instance, a cementation envelope (root tubule according to Klappa, 1980) along the roots can mimic a burrow wall. Moreover, root structures can co-occur with marine animal burrows, for instance, when roots penetrate into exposed soft marine sediments. In such cases carbonate sediments are usually quickly lithified, but roots can etch even very hard limestones and deeply penetrate the rock (James and Choquette,1989; A. Uchman, pers. observations). Nevertheless, meniscate fillings or constructed granulated walls are obvious features of animal burrows. The presence of a coaly lining is a common feature of roots (Sarjeant, 1975; Pieńkowski, 2004), but it may be oxidized and or consumed by detrivores. This feature is extremely rare in carbonate deposits.

In the Lower Pleistocene shallow-marine calcarenites of Favignana Island, southern Italy (Figs. 1 and 2), two types of large branched structures are present: (1) horizontal to oblique, and (2) vertical. Their interpretation as crustacean burrows or other animal trace fossils (A. Uchman) appeared problematic as shown by discussion during the Workshop on Crustacean Bioturbation - Fossil and Recent in Lepe, Spain, in 2010 (Gibert et al., 2010). Therefore, their alternative interpretation as root structures was considered, but some problems of such interpretation remain unsolved. Their description and interpretation are the main aim of this paper. They can be considered in the terms of ichnotaxonomy because root structures are not only body fossils (e.g., Pieńkowski, 2004) but also structures of recurrent shape, resulting from deformation of the substrate by a living organism (see Sarjeant, 1975; Bertling et al., 2006). Such practice has been adopted for root structures in Pleistocene calcarenites in Italy by D'Alessandro and Iannone (1982). However, casts of voids after roots can be also considered as 


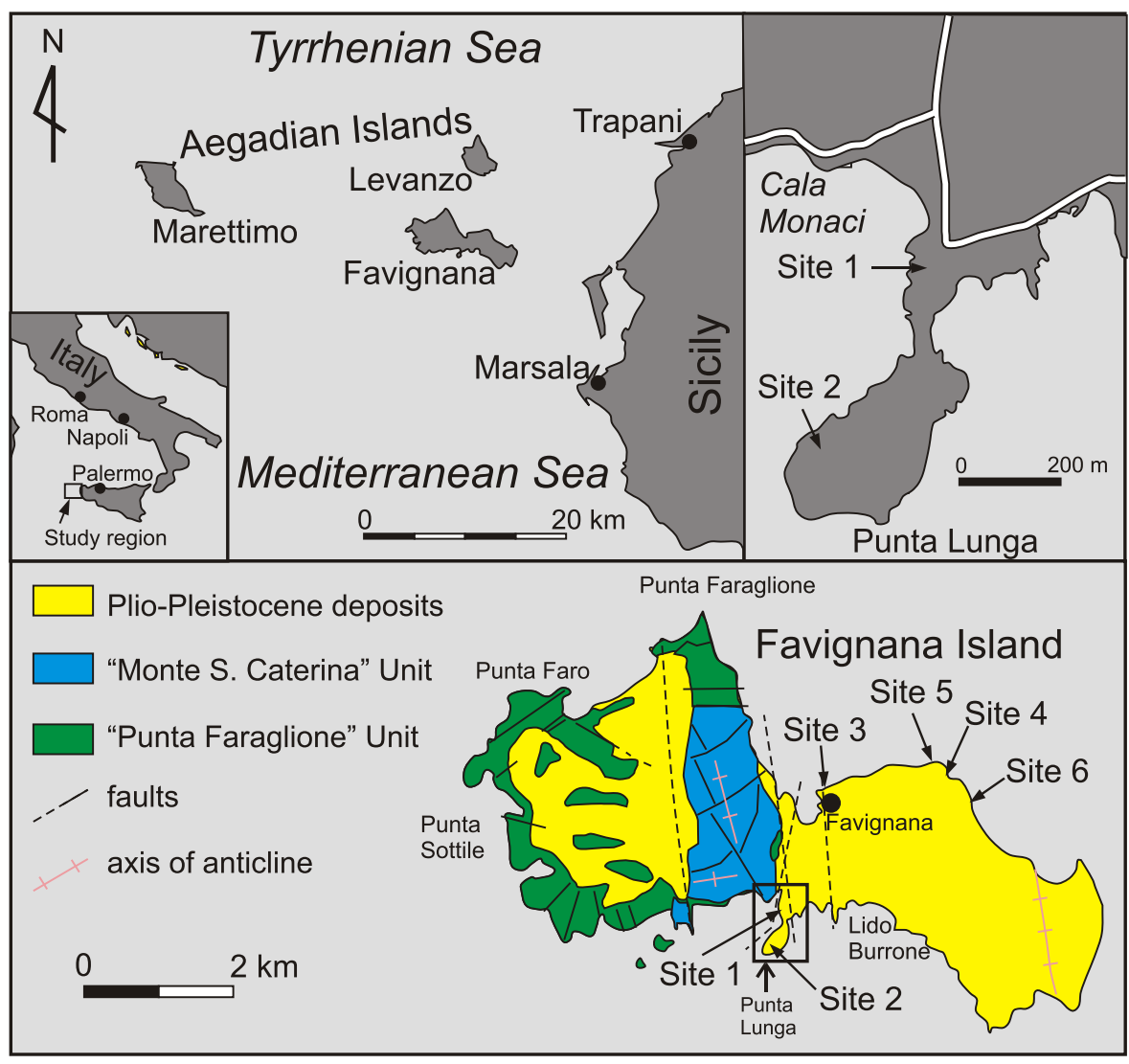

Fig. 1. Index map with locations of the sites studied

Geological map of Favignana Island redrawn from Abate et al. (1997)

external moulds of fossils. If they are body fossils of roots, the International Code of Botanical Nomenclature allows consideration of anatomical parts of a fossil plant as taxa (see McNeill et al., 2006; Division II, Chapter 1, Article 1.2). So, if they are roots their taxonomic description is still possible. In all cases, their taxonomic treatment imposes a descriptive discipline and makes comparisons easier, even if their systematic position is unclear.

\section{GEOLOGICAL SETTING}

Favignana Island belongs to the Aegadian Islands (Fig. 1) that represents an emerged part of the Egadi Thrust Belt (Abate et al., 1995, 1997) of the Sicilian-Maghrebian system. Favignana is mainly a build-up of Mesozoic-Upper Neogene carbonate deposits, which are unconformably covered by Middle-Upper Pliocene bluish marls and shales followed by Lower Pleistocene light calcarenites and calcirudites (Fig. 2). These deposits are covered by Tyrrhenian calcarenites and biorudites with Strombus bubonius,

Tyrrhenian, sand, gravels, bioclastics (1-4 m)

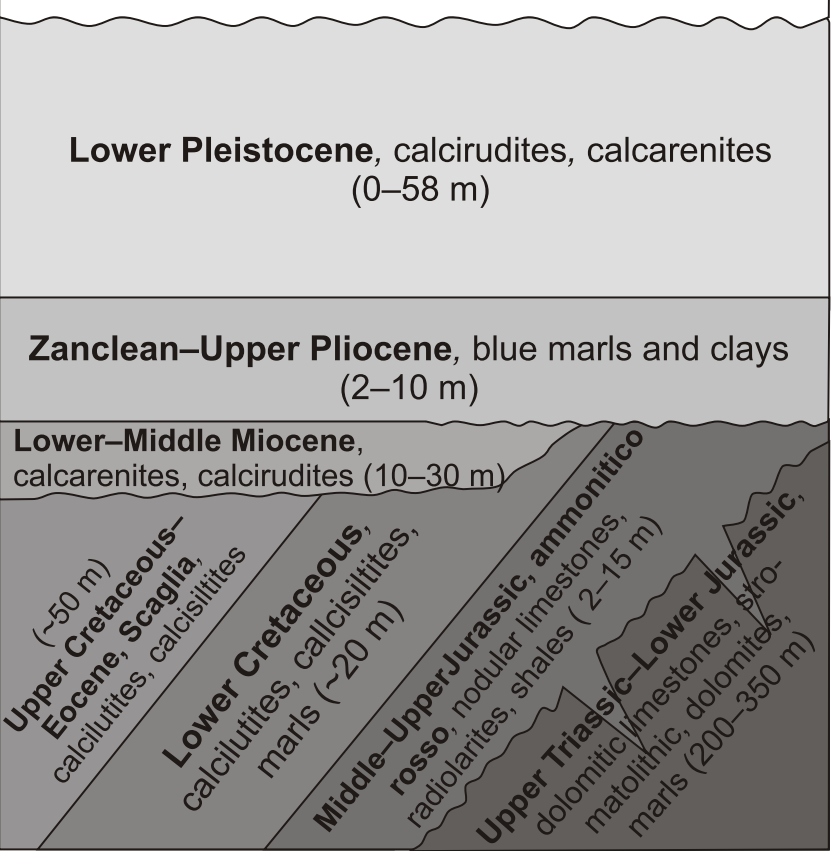

Fig. 2. Stratigraphic column of Favignana Island (after Abate et al., 1995, modified) which are separated from the underlying deposits by a reddish erosional discontinuity. The Lower Pleistocene deposits are widespread along the eastern slope of the emerged palaeoFavignana Island in a pull-apart basin, and are a part of a wide shoal that is attached to western Sicily and embraces the Aegadian Islands. The calcarenites have been quarried since Roman times. The Lower Pleistocene deposits represent a high energy coast with beach to offshore successions and a mobile bar system (Ślączka et al., 2011). Several facies associations are distinguished on the basis of bedform characteristics, sedimentary structures and ichnological features. They show an order in their distribution eastwards from the shoreline of the palaeo-Favignana Island, as described below. The foreshore-shoreface facies association generally is represented by a coarsening up sequence of calcarenites and conglomerates, which contain rare short, vertical tubular burrows. The upper shoreface facies association is characterized by calcirudites with several algal remains and rhodoliths, and these beds are separated by erosional surfaces that display Thalassinoides and Ophiomorpha. The upper-middle shoreface facies association is interpreted as the deposits of a bar system with erosional channels. Locally, it contains strongly bioturbated horizons and trace fossils of the Skolithos ichnofacies. The lower shoreface facies association is represented by a thick sequence of large-scale cross-bedded and subhorizontal laminated bedforms (outer bar system). Totally bioturbated horizons, mostly with echinoid burrows, mainly Scolicia, related to 
troughs between bars, are common here. Foresets of larger bedforms in all facies associations are steep, commonly avalanched, truncated by washouts and rip channels. These features suggest storm-dominated sedimentation. Storm periods were separated by fair-weather intervals, during which foresets were colonized by burrowing organisms, including echinoids (Ślączka et al., 2011).

The trace fossils studied occur in algal and rhodolithic calcirudites arranged in cross-bedded units up to few metres thick. Locally, medium bedded, homogeneous, mediumgrained calcarenites enriched in pelitic material are present, as well as coarsening-up strata, which are homogeneous in their lower part and low-angle laminated in their uppermost part, and topped by bioturbated calcirudites with lamination and muddy drapes. In some places, rhodolithic conglomerates crop out in thick beds with erosive bases, which are massive or crudely planar cross-bedded. Moreover, lenses of calcarenite rich in mollusc shells, up to $1.5 \mathrm{~m}$ thick, which display crude lamination in their lower parts and become more chaotic upwards, can be found. These deposits were formed by landward and seaward migrating subtidal dunes, which were influenced by storms, rip currents and in some horizons, by tsunamis (Ślączka et al., 2011).

\section{SYSTEMATIC PART}

Two taxa of root structures, tentatively interpreted as such, root mats and three ichnotaxa of typical animal trace fossils have been recognized. Some bioclasts from the localities studied contain invertebrate borings, which are not considered in this paper. Even if many aspects of the probable root structures remain unsolved, the reader may benefit from their descriptions.

\section{Faviradixus gen. nov.}

D e r i v a t i o $\mathrm{n}$ of $\mathrm{n}$ a $\mathrm{m}$ e. - From Favignana, the island of occurrence of the type species, and from radix (Latin) - root.

$\mathrm{T}$ y p e s p e c i e s. - Faviradixus robustus distinguished in this paper.

D i a g n o s i s. - Mostly horizontal to oblique, sparsely branched, slightly winding tubular structure with a thick "wall", without swellings in the branched point and any evidence of interconnections and interpenetrations.

R e m a r k s. - Faviradixus displays many similarities to the trace fossil Rhizoichnus D'Alessandro and Iannone, 1982, typified by Rhizoichnus firmus D'Alessandro and Iannone, 1982, from the Pleistocene of southern Italy, mainly by its thick "wall" and configuration of some segments. However, Rhizoichnus displays a more sinuous and locally helicoidal course, and fine hair-like ducts present in the axial part. Moreover, it is smaller (10-30 mm), and its common feature is micritization.

Faviradixus differs from Thalassinoides by convergence upwards of the tunnels, oblique dichotomous branching downwards, the smaller size of some branches, and a tendency to self avoidance. The differences point to side roots of a large tree as a possible agent. On the contrary, Thalassinoides shows mazes or boxworks composed of tunnels of similar size (e.g., Ekdale, 1992).

\section{Faviradixus robustus sp. nov. (Figs. 3-6)}

M a t e r i a l. - Holotype (Fig. 3A) - one specimen in the Dipartimento di Geologia, Universitŕ di Palermo. Moreover, one specimen ING UJ 183P8a (paratype; Fig. 5) in the Geological Museum of the Institute of Geological Sciences, Jagiellonian University. Tens of observations were made in the field and documented by photographs.

$\mathrm{D}$ e $\mathrm{r}$ i v a $\mathrm{t}$ i o $\mathrm{n}$ of $\mathrm{n}$ a $\mathrm{m}$ e. - From robust - sturdy in Latin, in reference to its large size.

D i a g n o s i s. - As for the ichnogenus.

D e s c r i p t i o n. - Rarely branched, inclined to horizontal, straight or slightly winding, tubular structures bounded by a "wall". The structure is circular or elliptical in cross section, 40-125 mm wide, traced for at least $250 \mathrm{~cm}$, forming galleries. The "wall" is 4-16 mm thick. Its surface is smooth, corrugated or rough or with holes, but without any ornamentation pattern. It is composed of coarse calcarenite, without any selection or arrangement of grains (Fig. 5B). The thickness of the "wall" is not uniform and changes around the perimeter of the structure. The lumen is commonly slightly off-centre (Fig. 3F).

Branches are sparse, running horizontally or obliquely down at an angle of $40-90^{\circ}$. They are of the same or smaller diameter (Fig. 3E). The inclination of the structural segments attains $30^{\circ}$. Dichotomous branches running obliquely down are also present (Figs. 3A and 4A). Locally, the tubes converge in a bench composed of 5-6 tubes, or converge obliquely up to a central point above the recent ground surface (Fig. 3C). Very rarely, patchy accumulations of the structures occur showing tubes running generally outwards (Fig. 3D). The branching tubes may run very close to each other or miss on slightly different levels, but never join again. They have a tendency to mutual avoidance. Only rarely cross-overs can be found, but they probably derive from different systems. In one specimen, a "tube-in-tube" structure was found, where a smaller tube penetrates along a larger tube in its upper part. The tubes penetrate along foresets and descend up to $130 \mathrm{~cm}$ below the modern ground surface (Fig. 3B).

The structure described co-occurs with horizontal to oblique and vertical galleries of the trace fossil Ophiomorpha nodosa Lundgren, 1891, with which there are cross-cutting relationships (Figs. 4A). However, it was impossible to determine the order of cross-cutting, and the characteristic granulated Ophiomorpha wall was not observed in the Faviradixus lumen. In rare cases, it seems that the Ophiomorpha wall enters the Faviradixus "wall", but the latter may be of diagenetic origin (see discussion of the species). Moreover, Ophiomorpha isp., Thalassinoides isp., and Beaconites isp. are present (Fig. 4C) at the same locality.

O c c u r r e n c e. - The most abundant occurrence is at site 1 at Punta Lunga (N3755.0686’; E012¹9.219’; \pm 4 m; Figs. 1 and 6). A few specimens were observed at site 2 ( $\mathrm{N}$ part of Punta Lunga) and at site 3 (just $\mathrm{N}$ of the harbour in Favignana; Fig. 1). 

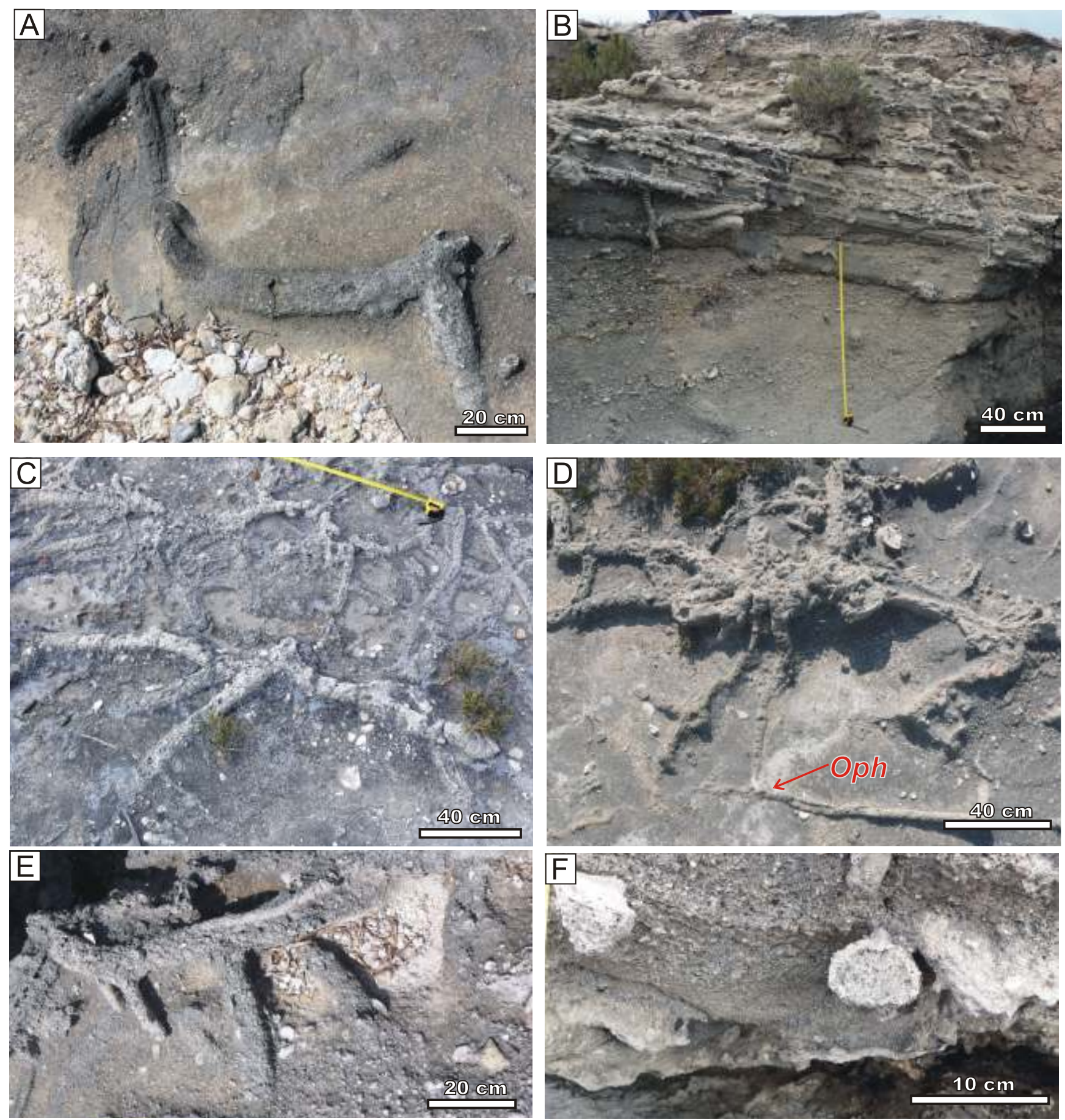

Fig. 3. Faviradixus robustus sp. nov. in Lower Pleistocene calcarenites of Punta Lungo, site 1

A - holotype before its excavation, view from the top; $\mathbf{B}$ - several tubular structures in large-scale cross-bedded calcarenites, side view; $\mathbf{C}$ - converging-up tubular structures, view from the top; D - coalescing tubular structures converged in a central area, Ophiomorpha nodosa (Oph), view from the top; $\mathbf{E}-$ branched tubular structures of different sizes, oblique view; $\mathbf{F}$ - cross-section with a distinct "wall"

D i s c u s s i o n. - The upwards convergence, spreading out from one point (see Sarjeant, 1975), oblique dichotomous branching down, the smaller size of some branches and, a tendency to self avoidance suggest interpretation of $F$. robustus as side roots of a large plant, probably a tree. Many tree roots show a similar pattern (Fig. 7). The "wall" (Fig. 5A) is not a constructed wall sensu Bromley (1996), which is typical of animal burrows, but rather a root tubule sensu Klappa (1980) orig- inating by diagenetic cementation. The off-centre position of the lumen is typical of the other named root structure Rhizoichnus D'Alessandro and Iannone, 1982. The tube was filled passively by calcarenitic sediment, maybe due to filling of voids by marine sediment after the roots decayed. Rare cross-overs, including "tube-in-tube" occurrences, can be explained by penetration of a living root into a dead one. Co-occurrence with marine animal trace fossils is possible because 


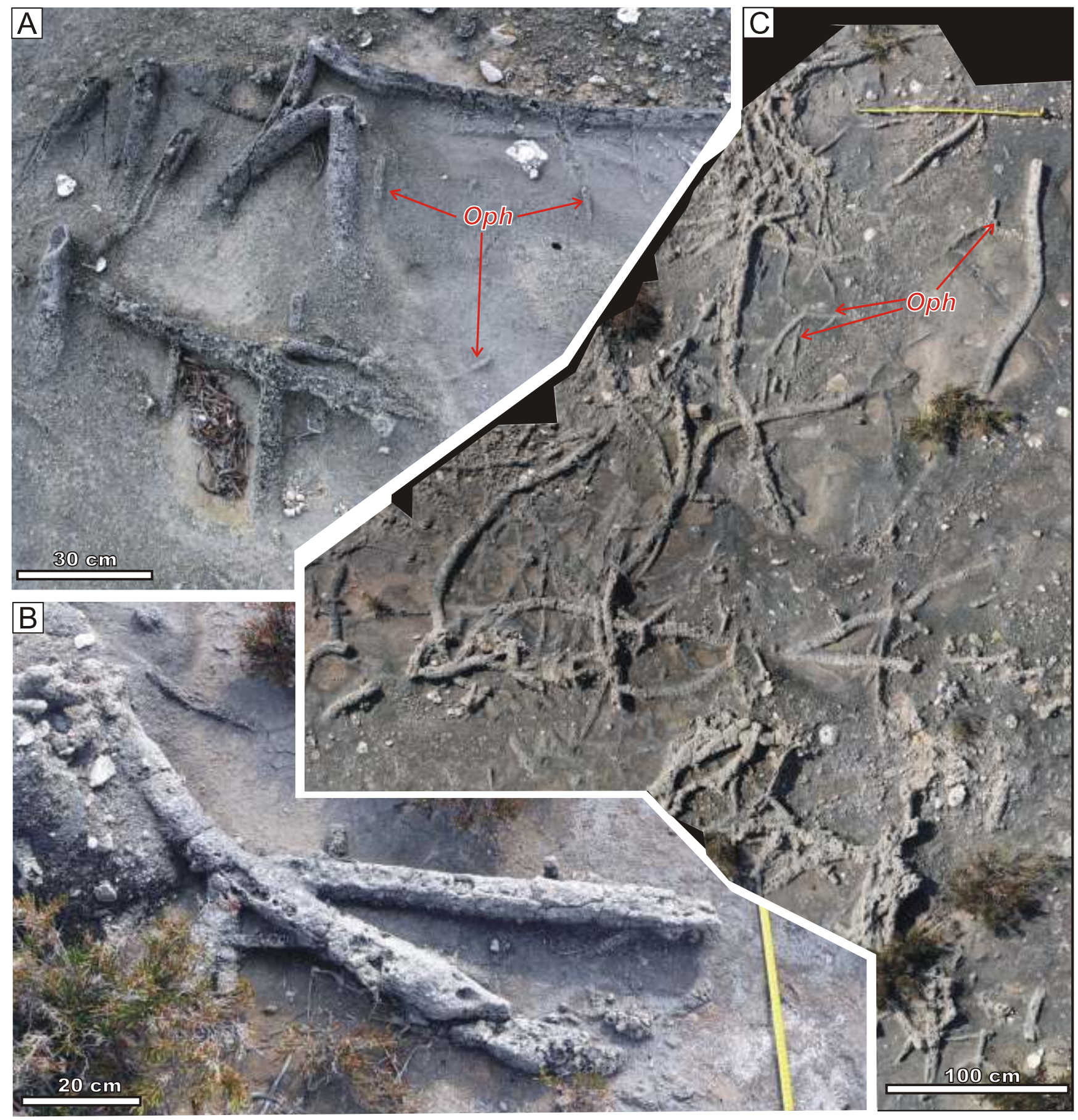

Fig. 4. Faviradixus robustus sp. nov. in Lower Pleistocene calcarenites in Punta Lungo, site 1

A - branched specimens and Ophiomorpha nodosa $(O p h)$, oblique view; $\mathbf{B}$ - branched specimens, oblique view; $\mathbf{C}$ - photomosaic with $F$. robustus, Beaconites isp. and Ophiomorpha nodosa $(\mathrm{Oph})$

penetration by roots can start from a higher and younger continental colonization surface. Nevertheless, the absence of preserved soil or karst surface above, the absence of remnants of wood of organic matter, and the absence of significant micritization around the "wall" (Fig. 5C) makes this interpretation provisional.

Among trace fossils, only the crustacean burrow Thalassinoides Ehrenberg, 1944 is similar, but none of the known ichnospecies fits the structure described. It is expected that branches will be more common in Thalassinoides, with swelling at branch junctions, and the burrows will form a maze or box-work pattern, where the burrows can rejoin after branching (e.g., Ekdale, 1992).

\section{Egadiradixus gen. nov.}

D e r i v a t i o n o f $\mathrm{n}$ a m e. - From the Aegadian Islands, which include Favignana, the island of occurrence of the type ichnospecies, and from radix (Latin) - root. 

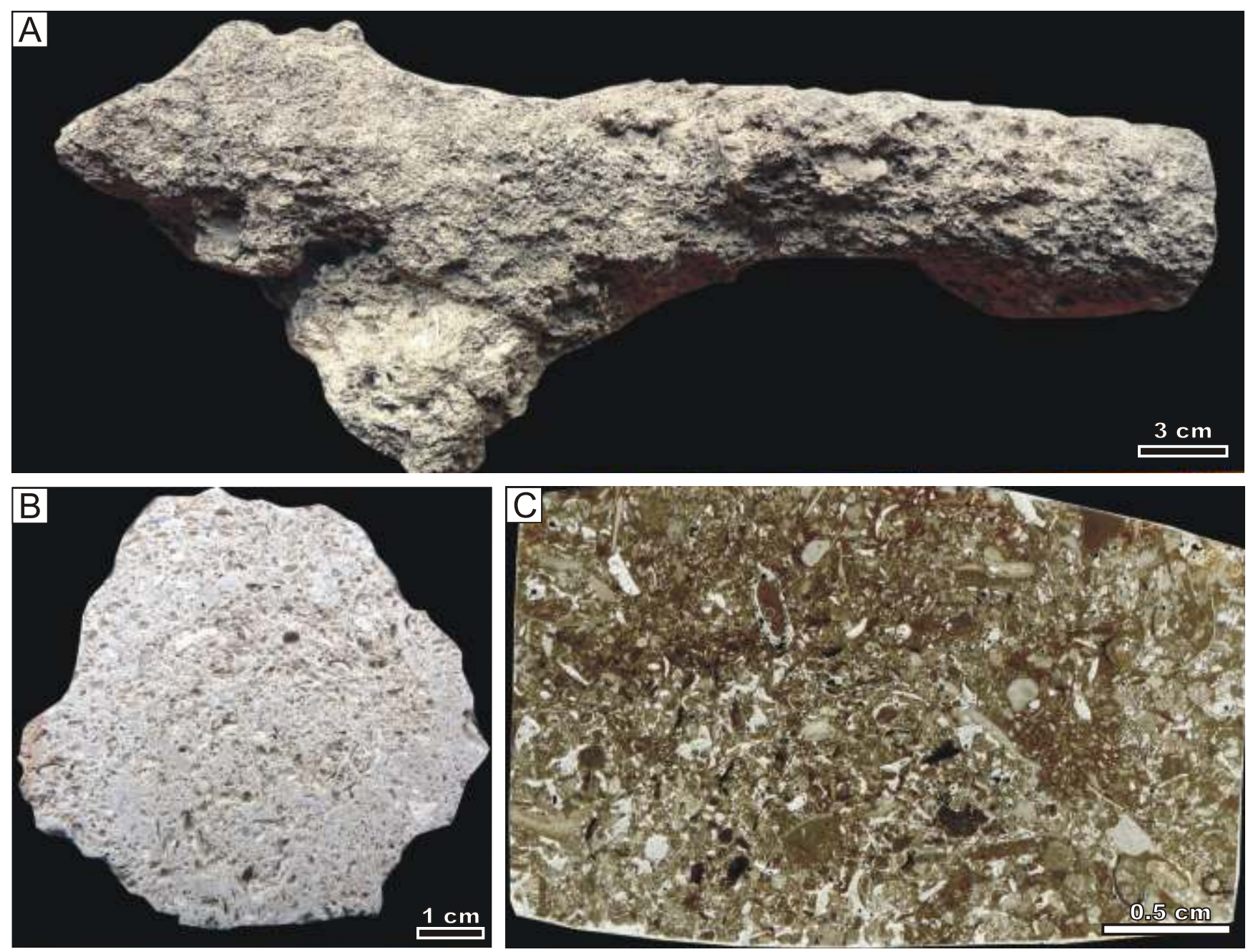

Fig. 5. Faviradixus robustus sp. nov.

A - paratype, INGUJ183P8a; B - paratype in cross-section showing biocalcarenite in the filling and the "wall”, INGUJ 183P8b; C - thin section from B

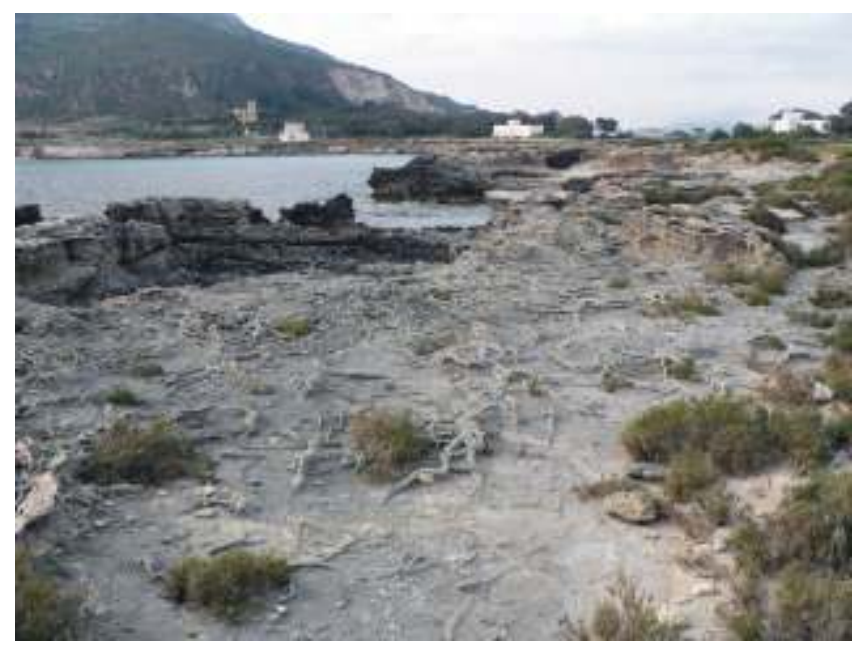

Fig. 6. Rock surface with Faviradixus robustus sp. nov. in Punta Lungo, site 1
T y p e s p e c i e s. - Egadiradixus rectibrachiatus distinguished in this paper.

Di agnosis. - Vertical, tapering down or equidimensional shaft with simple, straight branches running obliquely downwards. At least part of the branches display a smaller dimension than the shaft.

$\mathrm{R}$ e $\mathrm{m}$ a r k s. - The morphology expressed in the diagnosis is unique, different from crustacean burrows, e.g., Ophiomorpha Lundgren, 1891, Psilonichnus Fürsich, 1981, or Thalassinoides Ehrenberg, 1944 (e.g., Frey et al., 1984), the only candidates among animal trace fossils. This structure can be related to the taproots of higher plants.

Egadiradixus rectibrachiatus $\mathrm{sp}$. nov. (Figs. 8 and 9)

D e rivation of $\mathrm{n}$ a m e. - From rectus (Latin) straight, and brachiatus (Latin) - having branches, in correspondence to the general shape. 

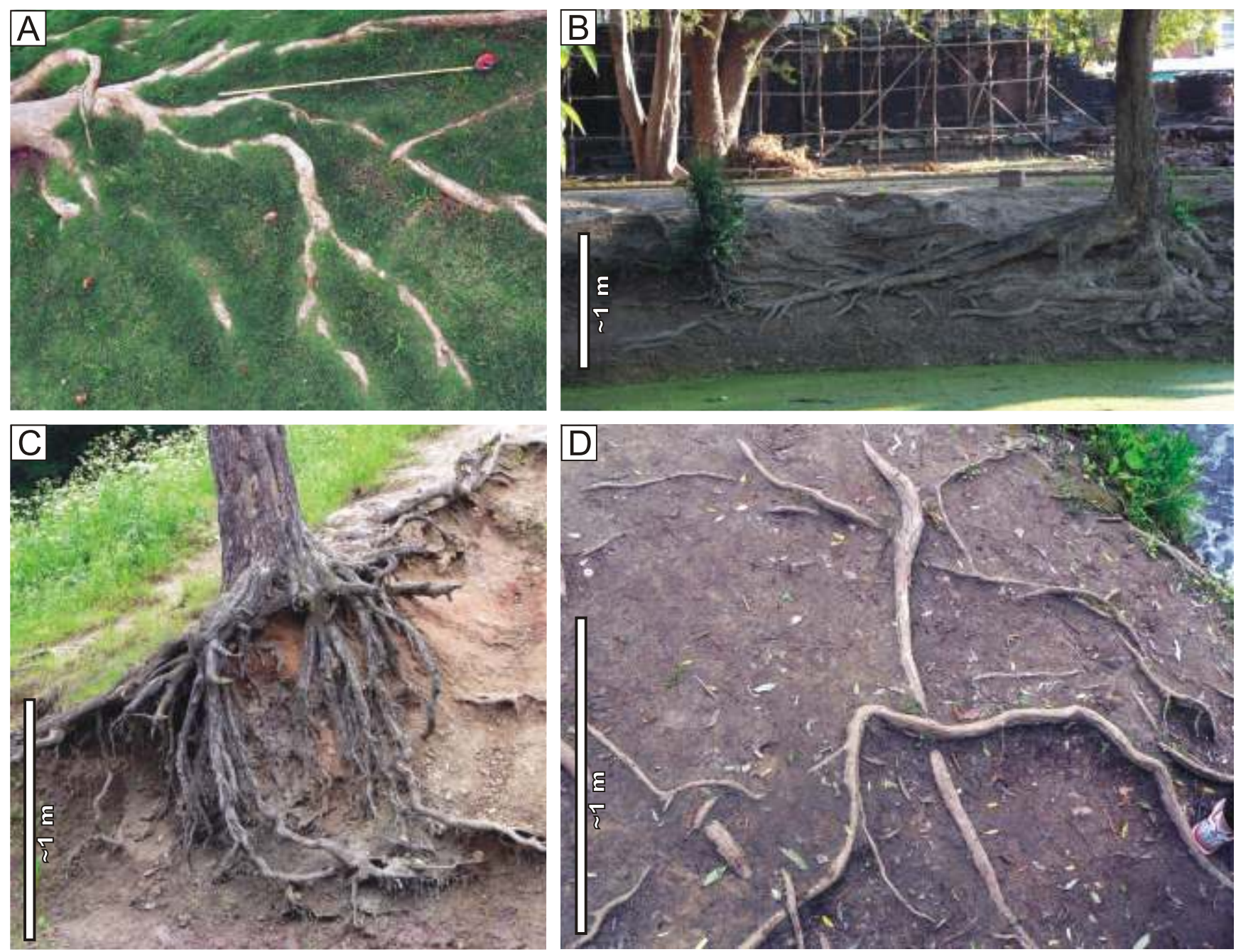

Fig. 7. Example of roots of recent trees

A - silk floss tree (Ceiba specios; palo borracho), Huelva, southern Spain; B - unknown deciduous tree, Pimai, Thailand; C - pine (Pinus sp.), Sankt Petersburg region, Russia; D - willow (Salix sp.), Sankt Petersburg region, Russia

M a t e $\mathrm{r}$ i a 1. - The holotype (Fig. 8A) was left in the field because its collection, would require the cutting of a large rock slab. Moreover, six specimens in the field are documented by photographs at site 4 (Frascia, S of cemetery; GPS coordinates: $\mathrm{N} 37^{\circ} 56.036^{\prime}$; E012 $20.945^{\prime} ; \pm 5 \mathrm{~m}$ ), site 5 (GPS coordinates: N37 $56.170^{\prime} ; \mathrm{E} 012^{\circ} 20.624^{\prime} ; \pm 6 \mathrm{~m}$ ), and site 6 (Cavallo 1).

D i a g n o s i s. - Vertical shaft with simple, straight, branches running obliquely downwards. The branches are elliptical in cross-section and of smaller dimension than the shaft.

D e s c ri p tion. - Sub-vertical, almost straight or slightly winding central cylindrical structure without wall or only with a thin lining, smooth, up to at least $110 \mathrm{~cm}$ long, irregularly tapering down. Some specimens, including the holotype (Fig. 8A), display gentle swellings and constrictions from 25 to $30 \mathrm{~mm}$, at intervals of $15-25 \mathrm{~cm}$. The central cylinder displays rare, straight, simple, tubular branches, circular or elliptical in cross-section, mostly $5-8 \mathrm{~mm}$ wide, rarely up to $20 \mathrm{~mm}$ wide, up to $120 \mathrm{~mm}$ long, running downwards at the angle ranging from 15 to $40^{\circ}$ with respect to the horizontal plane. In one case, the central structure diverges downwards at a very low angle and passes into two cylindrical structures running al- most parallel (Fig. 8C). Very rarely dichotomous second-order branches occur (Fig. 8C). Some of the associated trace fossils do not display branches at exposure (Fig. 8E). They resemble the animal trace fossil Skolithos or Macanopsis (those with enlargements at the base, see Fig. 9); however, their size and preservation suggest that they belong to E. rectibrachiatus, where branches are not visible in some sections.

D i s c u s s i o n. - The tapering down, smaller width of the side branches and dichotomous diverging downwards are features typical of roots (cf. Klappa, 1980). Smaller roots of the same morphology from the Eocene have been illustrated by Plaziat (1971, fig. 3). The locally present lining, which is composed of finer limestone than the filling and the surrounding rock, probably represents a root tubule, with the tubule having formed as a cementation envelope around roots (Klappa, 1980). Any known crustacean or other animal burrow does not display a similar pattern. Because of its size and pattern, Egadiradixus rectibrachiatus is interpreted as a cast of taproot of a higher plant, probably a tree or a bush. The voids after decayed roots may have been filled by calcarenite brought in by marine flooding. 

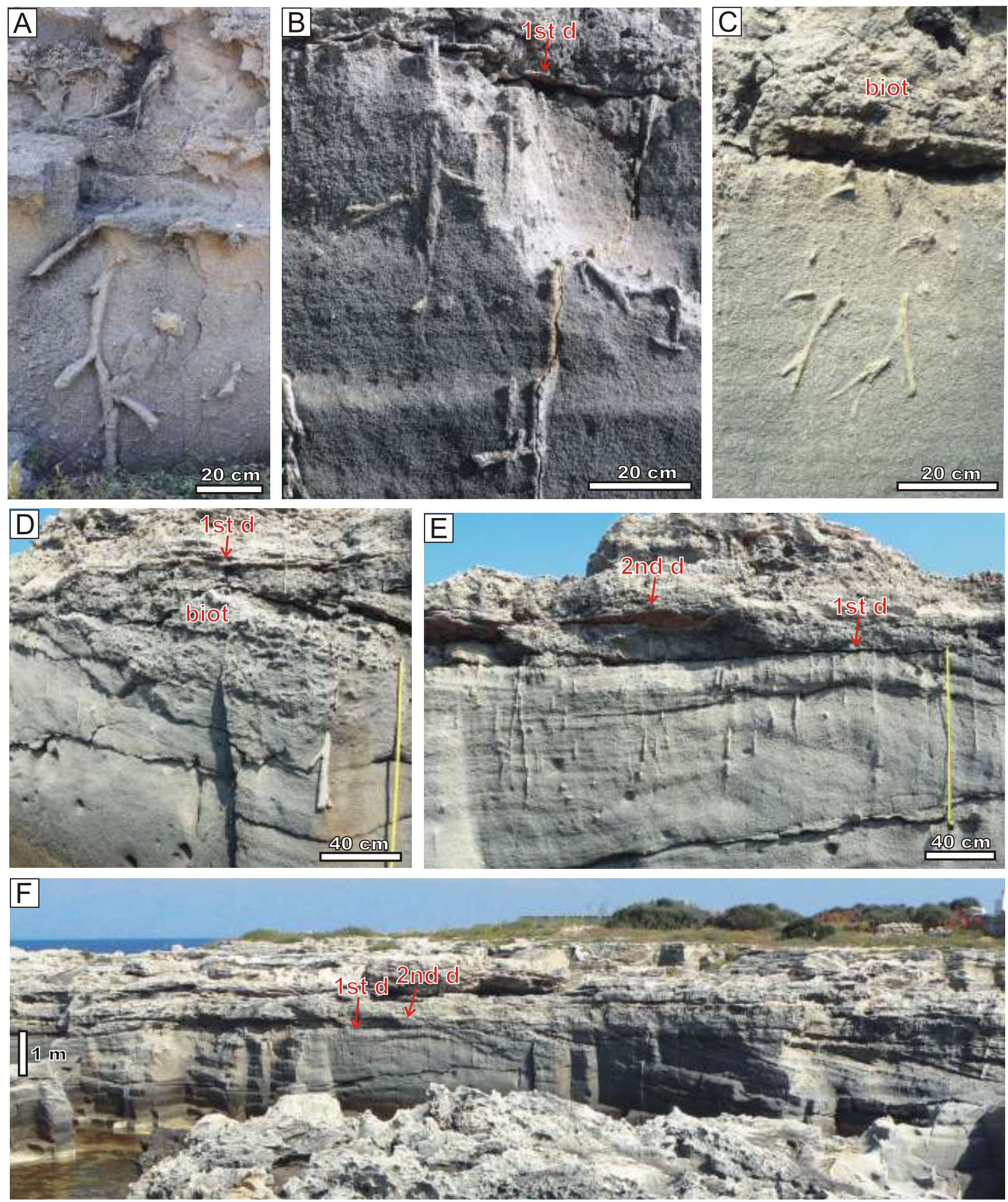

Fig. 8. Egadiradixus rectibrachiatus sp. nov. in Lower Pleistocene calcarenites, Frascia, S of cemetery, site 3

A-holotype (still in the field); $\mathbf{B}, \mathbf{C}$ - other specimens: 1st d-first discontinuity, biot - bioturbated layer; $\mathbf{D}$-specimen with side branches of smaller diameter, bioturbated layer (biot) at the top of the host cross-bedded set, below the first discontinuity (1st d); $\mathbf{E}-$ E. rectibrachiatus, branched and apparently unbranched, ?Skolithos-like specimens below the first (1st d) and second (2nd d) discontinuities; $\mathbf{F}$ - general view of site 3 showing horizontally laminated calcarenites overlying the cross-bedded unit with E. rectibrachiatus, below the first (1st d) and second (2nd d) discontinuities 


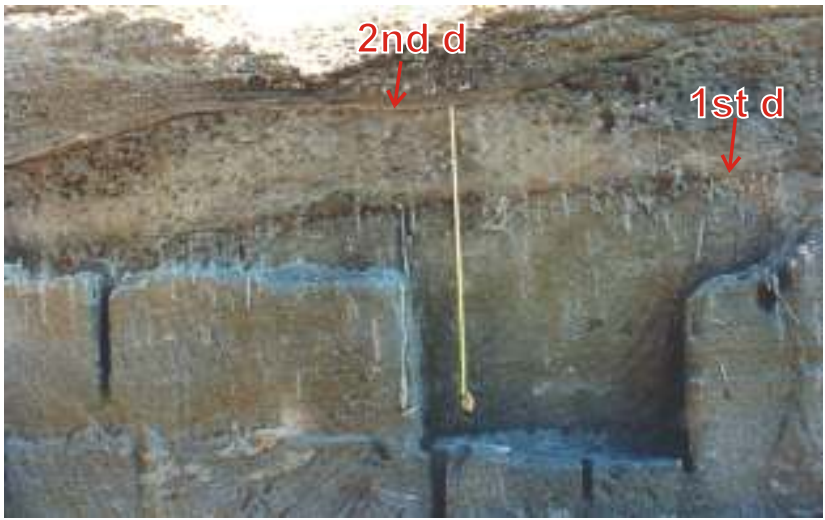

Fig. 9. ?Egadiradixus rectibrachiatus sp. nov. in Lower Pleistocene calcarenites, Frascia, $S$ of cemetery, site 3

?Skolithos-like and Macanopsis-like specimens below the first (1st d) and second (2nd d) discontinuities

Root mats

(Fig. 10)

D e s c r i p t i o n. - Tubular, slightly winding, branched, unlined or thinly lined structures built of calcium carbonate, 1-5 mm wide (Fig. 10A, B) or 2-5 mm wide (Fig. 10C). The branches are of smaller dimension than the master tunnels. Commonly, they overlap and form a dense, irregular network.

$\mathrm{R}$ e $\mathrm{m}$ a r k s. - The root mats belong probably to small shrubs, as are currently common in the island. They occur on several erosional or lamination surfaces, most of which are younger (Tyrrhenian and younger) than the structures described.

\section{ASSOCIATED ANIMAL TRACE FOSSILS}

Faviradixus robustus co-occurs with Ophiomorpha nodosa, Ophiomorpha isp., Thalassinoides isp., and Beaconites isp. No animal trace fossils are associated with Egadiradixus rectibrachiatus, except for tubular forms that could be interpreted as Skolithos isp., which is a common trace fossil in high-energy shallow marine deposits. But more probably these tubular forms represent incomplete $E$. rectibrachiatus, as they penetrate from the same surfaces, and display the same size parameters and mode of preservation.

Ophiomorpha nodosa Lundgren, 1891 (Fig. 11A, C) is a common trace fossil in shallow marine deposits. It forms a system of vertical, oblique and horizontal tubular burrows, the wall of which consists predominantly of dense, regularly distributed discoid, ovoid or irregular polygonal pellets (see Frey et al., 1978). The tube is $8-35 \mathrm{~mm}$, mostly $19-30 \mathrm{~mm}$, in exterior diameter. The pellets are up to $8 \mathrm{~mm}$ long and $5 \mathrm{~mm}$ wide. Commonly the pellets are elongated perpendicular to the burrow axis. The segments between branching points are straight to slightly curved or winding, up to $60 \mathrm{~cm}$ long. The branches are Y-or T-shaped. The branch junctions are slightly enlarged.
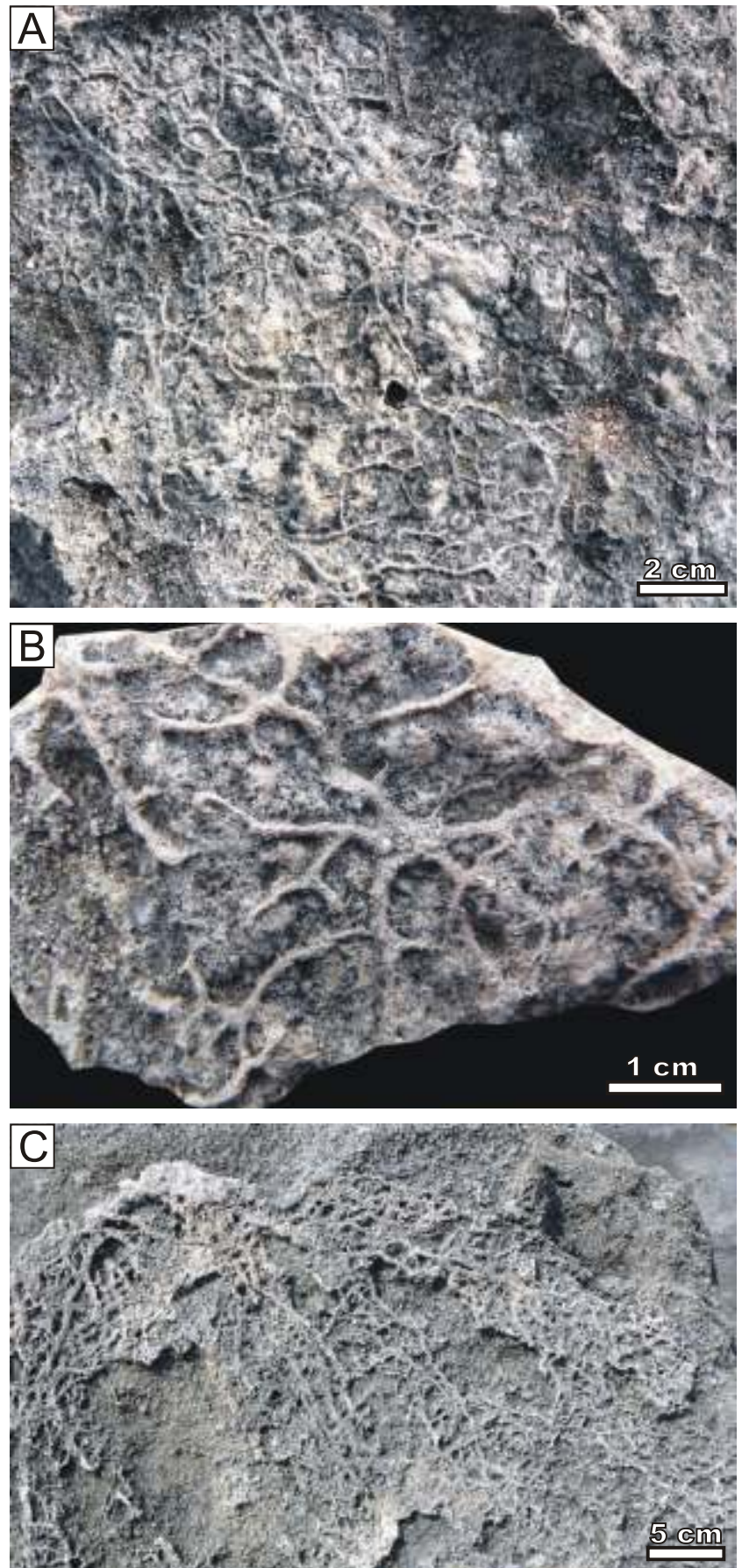

Fig. 10. Root mats

A - ? Tyrrhenian surface covered with root mats, Lido Burrone; B - closer view of the specimen NGUJ183P9, Lido Burrone; $\mathbf{C}-$ ?Tyrrhenian surface covered with root mats; Frascia, $\mathrm{S}$ of cemetery, near site 3

Ophiomorpha nodosa is produced mostly by callianassid shrimps (Frey et al., 1978; Ekdale, 1992). It is most typical of the Skolithos ichnofacies (Frey and Seilacher, 1980; Pemberton et al., 2001), but also occurs in deeper shelf tempestites (Frey, 1990; Frey and Goldring, 1992).

Exceptionally large Ophiomorpha isp. (Fig. 11B), $52 \mathrm{~mm}$ in diameter, was exposed as an unbranched horizontal segment. Pellets in its wall are more or less oval. This trace fossil is rare. 

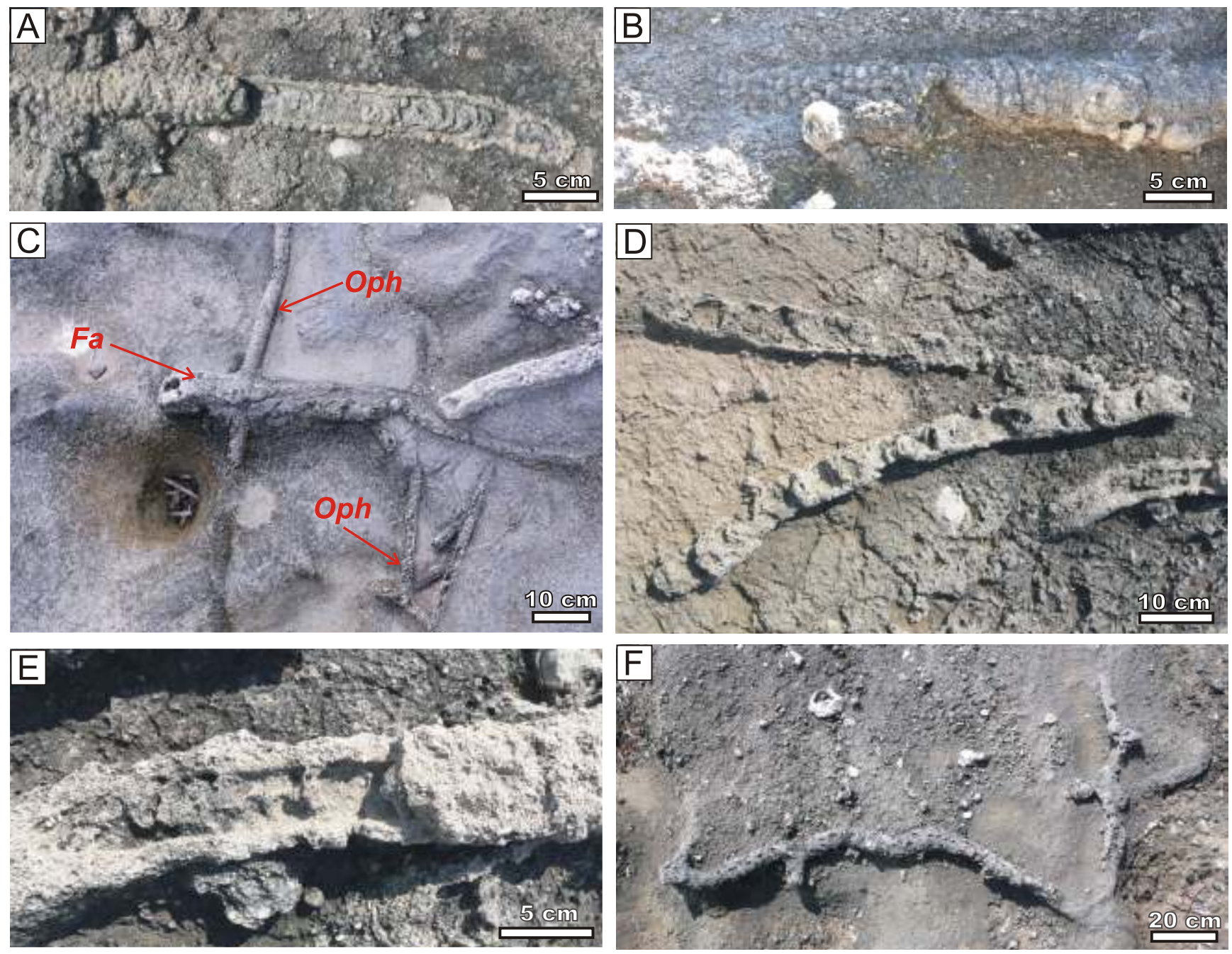

Fig. 11. Other trace fossils from the sites studied (top views of horizontal surface)

A - Ophiomorpha nodosa with the pelleted wall and a partly meniscate filling, horizontal; B - Ophiomorpha isp.; C - Faviradixus robustus (Fa) and Ophiomorpha nodosa $(O p h) ; \mathbf{D}, \mathbf{E}-$ Beaconites isp.; $\mathbf{F}-$ Thalassinoides isp.

Thalassinoides isp. (Fig. 11F) consists of horizontal, branched, tubular burrows, which are $3-6 \mathrm{~cm}$ wide. Trace fossils of this ichnogenus are produced mostly by decapod crustaceans (Frey et al., 1984; Ekdale, 1992) in several marine, mostly shallow-water environments.

Beaconites isp. (Fig. 11D, E) is a gently winding, horizontal burrow, $55 \mathrm{~mm}$ wide, with a thick wall-like structure that is up to $8 \mathrm{~mm}$ wide. It is filled with crudely meniscate sediment as in the surrounding rock. This trace fossil displays features of the ichnogenus but does not fit to the known ichnospecies of Beaconites, which can occur in non-marine and shallow-marine sediments (see Keighley and Pickerill, 1994).

\section{DISCUSSION}

Faviradixus and Egadiradixus resemble large crustacean burrows, but the similarity is apparent. Both of them display at least parts of branches, with dimensions smaller than the master tube and strong self avoidance. Neither form displays a granulated wall or a meniscate filling, which are typical features of animal burrows. Crustacean burrows rather form mazes or boxworks, with swellings, especially at where branches join. These features suggest plant roots, the taphonomy of which is poorly understood, while classification in the fossil record is underdeveloped. Therefore, with hesitation, we interpret them as plant root structures.

Faviradixus robustus and Egadiradixus rectibrachiatus are structures that deeply penetrate marine deposits containing marine macrofossils and trace fossils. They penetrated from continental surfaces, which are not preserved at the sites of their occurrence. The surfaces were high enough to keep the water table at a depth of at least $1.5-2 \mathrm{~m}$, allowing the roots to live in well-oxygenated ground. In the case of a shallow water table, roots are short, thick and iron minerals are abundant (Sarjeant, 1975; Arndorff, 1993; Pieńkowski, 2004). Good oxygenation of the substrate is probably responsible for absence of the carbonized lining. Deep roots, up to $3.5 \mathrm{~m}$ long, penetrating deposits with marine trace fossils, are known from the Pleistocene deposits of the Tyrrhenian Sea coast (D'Alessandro et al., 1993).

Egadiradixus rectibrachiatus penetrates a cross-bedded coarse calcarenite, upper part of which $(30-40 \mathrm{~cm})$ is 
bioturbated (Fig. 8C, D). The lower calcarenites are overlain by horizontally bedded coarse calcarenites (Fig. 8D, F). E. rectibrachiatus initiates from two more or less even discontinuities (Figs. 8B, D-F and 9): the first is located between the two calcarenites and a second one, $30 \mathrm{~cm}$ higher, is located within the horizontally bedded calcarenite. The discontinuities are marked by a thin brownish crust. We interpret these discontinuities as representing horizons of emergence, other features of which have been destroyed by subsequent erosion. The brownish crust may be an initial pozdol-type palaeosol (cf. Arndorff, 1993) or a penetrative calcrete associated with a higher emergence horizon that was subsequently truncated by erosion. More problematic is the colonization surface for Faviradixus robustus, because overlying sediments are not preserved at its localities. The candidate surface is the discontinuity between the Calabrian calcarenites and the Tyrrhenian strata. However, the Tyrrhenian deposits display a characteristic lithology, which would be expected in the fillings of the structures - which, however, are identical to the surrounding Calabrian calcarenites (Fig. 6). This does not exclude this discontinuity as a continental colonization surface, because colonization by plants might take place at the beginning of formation of this discontinuity, before sedimentation of the Tyrrhenian deposits, when the Calabrian calcarenites were erosionally remobilized. Alternatively, the continental colonization surface does not need to be hard. In Pleistocene carbonates of Tunisia, Plaziat and Mahmoudi (1990) observed empty root tubules, $2-20 \mathrm{~cm}$ in diameter, that start from aeolianite and continue down for up to $2-5 \mathrm{~m}$. It seems that the tubules represent void tubes after roots in a loose sediment. The consistency of the substrate is not a crucial problem, because roots can penetrate in soft as well in hard substrates (Klappa, 1980). It is also possible that the area was briefly emergent during the Pleistocene and colonized by plants; however, any discontinuities, karst phenomena or pedogenic features are so far unknown from this interval. On the other hand, eleven marine terrace levels distinguished on the Tyrrhenian Sea coast (Brückner, 1980; Cucci and Cinti, 1998; Zander et al., 2006) indicate the high mobility of this area, which can cause short emergence events while further sea flooding can destroy evidence of terrestrial processes.

It can be concluded that the existence of emergence as well as interpretation of the roots structures in the Lower Pleistocene carbonates of Favignana remain problematic to some degree. These problems require further research on the island and elsewhere in the region.

Acknowledgements. This research has been supported by the Jagiellonian University (DS funds) and the Dipartimento di Geologia, Università di Palermo. C. Carvalho (Idanha-a-Nova, Portugal) and other participants the Workshop on Crustacean Bioturbation - Fossil and Recent in Lepe, Spain, in 2010, are acknowledged for constructive discussions regarding the root structures. G. Pieńkowski (Warsaw), R. Mikuláš (Prague) and H. A. Curran (Northampton, Massachusetts) provided helpful critical reviews, however, we do not agree with Curran who considers that the structures described should not be named. The paper benefited from a discussion on the taxonomy of root structures with A. K. Rindsberg (Livingston, Alabama), J. F. Genise (Buenos Aires) and M. Bertling (Münster).

\section{REFERENCES}

ABATE B., FERRUZZA G., INCANDELA A. and RENDA P. (1995) Tettonica trascorrente nelle Isole Egadi Sicilia Occidentale. Studia Geol. Camerti, Vol. Spec., 2: 9-14.

ABATE B., INCANDELA A. and RENDA P. (1997) - Carta Geologica delle Isole di Favignana e Levanzo. Dipartimento di Geologia e Geodesia, Univ. Palermo

ARNDORFF L. (1993) - Lateral relations of deltaic palaeosols from the Lower Jurassic Rønne Formation on the island of Bornholm. Denmark. Palaeogeogr. Palaeoclimatol. Palaeoecol., 100: 235-250.

BERTLING M., BRADDY S., BROMLEY R.G., DEMATHIEU G.D., GENISE J.F., MIKULÁŠ R., NIELSEN J.-K., NIELSEN K.S.S., RINDSBERG A.K., SCHLIRF M. and UCHMAN A. (2006) - Names for trace fossils: a uniform approach. Lethaia, 39: 265-286.

BOYD D.W. (1975) - False or misleading traces. In: The Study of Trace Fossils (ed. R.W. Frey): 65-83. Springer Verlag, Berlin, Heidelberg, New York.

BROMLEY R.G. (1996) - Trace Fossils. Biology, Taphonomy and Applications. Second Edition. Chapman and Hall, London.

BRÜCKNER H. (1980) - Marine Terrassen in Süditalien. Eine quartärmorphologische Studie über das Küstentiefland von Metapont. Düsseldorfer Geogr. Schrift., 14: 1-235

CUCCI L. and CINTI F.R. (1998) - Regional uplift and local tectonic deformation recorded by the Quaternary marine terraces on the Ionian coast of northern Calabria (southern Italy). Tectonophysics, 292: 67-83.

CURRAN H.A. (1984) - Ichnology of Pleistocene carbonates on San Salvador, Bahamas. J. Sedim. Petrol., 58: 312-321.
D'ALESSANDRO A. and IANNONE A. (1982) - Pleistocene carbonate deposits in the area of Monopoli (Bari Province): sedimentology and palaeoecology. Geol. Rom., 21: 603-653.

D'ALESSANDRO A., LOIACONO F. and BROMLEY R.G. (1993) - Marine and nonmarine trace fossils and plant roots in a regressional setting (Pleistocene, Italy). Riv. Ital. Paleont. Strat., 98: 495-522.

EHRENBERG K. (1944) - Ergänzende Bemerkungen zu den seinerzeit aus dem Miozän von Burgschleinitz beschrieben Gangkernen und Bauten dekapoder Krebse. Paläont. Zt., 23: 354-359.

EKDALE A.A. (1992) - Muckraking and mudslinging: the joys of deposit-feeding. Short Courses in Paleontology, 5: 145-171.

EKDALE A.A., BROMLEY R.G. and PEMBERTON G.S. (1984) Ichnology: the use of trace fossils in sedimentology and stratigraphy. SEPM Short Course, 15: 1-317.

FREY R.W. (1990) - Trace fossils and hummocky cross-stratification, Upper Cretaceous of Utah. Palaios, 5: 203-218.

FREY R.W. and GOLDRING R. (1992) - Marine event beds and recolonization surfaces as revealed by trace fossil analysis. Geol. Mag., 129: 325-335.

FREY R.W. and SEILACHER A. (1980) - Uniformity in marine invertebrate ichnology. Lethaia, 23: 183-207.

FREY R.W., HOWARD J.D. and PRYOR W.A. (1978) - Ophiomorpha: its morphologic, taxonomic, and environmental significance. Palaeogeogr. Palaeoclimatol. Palaeoecol., 23: 199-223. 
FREY R.W., CURRAN H.A. and PEMBERTON G.S. (1984) - Trace making activities of crabs and their environmental significance: the ichnogenus Psilonichnus. J. Paleont., 58: 333-350.

FÜRSICH F.T. (1981) - Invertebrate trace fossils from the Upper Jurassic of Portugal. Com. Serv. Geol. Portugal, 67: 153-168.

GIBERT J. de, MUYIZ F., MAYORAL E. and BELAÚSTEGUI Z., eds. (2010) - Workshop on Crustacean Bioturbation Fossil and Recent, Lepe, Spain, May 31-June 4, 2010, Abstract Volume. Lepe.

GREGORY M.R. and CAMPBELL K.A. (2003) - A 'Phoebichnus look-alike': a fossilised root system from Quaternary coastal dune sediments, New Zealand. Palaeogeogr. Palaeoclimatol. Palaeoecol., 192: 247-258.

JAMES N.P. and CHOQUETTE P.W. (1989) - Diagenesis 9. Limestones: The meteoric diagenetic environment. In: Carbonate Sedimentology and Petrology (eds. P.A. Scholle, N.P. James and J.F. Read). Short Course in Geology, 4: 45-78.

KEIGHLEY D.G. and PICKERILL R.K. (1994) - The ichnogenus Beaconites and its distinction from Ancorichnus and Taenidium. Palaeontology, 37: 305-337

KLAPPA C.F. (1980) - Rhizoliths in terrestrial carbonates: classification recognition, genesis and significance. Sedimentology, 27: 613-629.

LUNDGREN B. (1891) - Studier öfver fossilförande lösa block. Geol. Fören. Stockholm Förhandl., 13: 111-121.

McNEIL J., BARRIE F.R., BURDET H.M., DEMULIN V., HAWKSWORTH D.L., MARHOLD J.H., NICOLSON D.H., PRADO J., SILVA P.C., SKOGE J.E., WIERSEMA J.H. and TURLAND N.J., eds. (2006) - International Code of Botanical Nomenclature (Vienna
Code): adopted by the Seventeenth International Botanical Congress Vienna, Austria, July 2005. Regnum Vegetabile, 146. A.R.G. Gantner Verlag KG, Ruggell, Liechtenstein.

PEMBERTON G.S., SPILA M., PULHAM A.J., SAUNDERS T., MacEACHERN J.A., ROBBINS D. and SINCLAIR I.K. (2001) Ichnology and sedimentology of shallow to marginal marine systems: Ben Nevis and Avalon Reservoirs, Jeanne D'Arc Basin. GAC Short Course Notes, 15: 1-343.

PIEŃKOWSKI G. (2004) - The epicontinental Lower Jurassic of Poland. Polish Geol. Inst. Spec. Pap., 12: 1-154.

PLAZIAT J.-C. (1971) - Racines ou terriers? CritPres de distinction B partir de quelques exemples du Tertiaire continental et littoral du bassin de Paris et du midi de la France. Conséquences paléogéographiques. Bull. Soc. Géol. France, Sér. 7, 13 (1-2): 195-203.

PLAZIAT J.-C. and MAHMOUDI M. (1990) - The role of vegetation in Pleistocene eolianite sedimentation: an example from Eastern Tunisia. J. Afr. Earth Sc., 10: 445-451.

SARJEANT W.A.S. (1975) - Plant trace fossils. In: The Study of Trace Fossils (ed. R. W. Frey): 163-179. Springer, New York.

ŚLACZKA A., NIGRO F., RENDA P. and FAVARA F. (2011) - Lower Pleistocene deposits in east part of the Favignana Island, Sicily, Italy. Il Quaternario, 24: 7-23.

ZANDER A., FÜLLING A., BRÜCKNER H. and MASTRONUZZI G. (2006) - OSL dating of Upper Pleistocene littoral sediments: a contribution to the chronostratigraphy of raised marine terraces bordering the Gulf of Taranto, South Italy. Geogr. Fis. Dinam. Quat., 29: 33-50. 